\title{
Language as Archive: Etymologies and the Remote History of Spain
}

\author{
Valeria López Fadul
}

In 1592 the Jesuit historian Juan de Mariana (1536-1624) articulated a devastating and lengthy critique against scholars who employed etymological proofs to trace the origins of people. ${ }^{1}$ He took issue with the idea that the names of places contained immutable traces of their founders. It was incorrect to assert, for instance, that the Portuguese region of Setubal was first established by the Biblical king Tubal, the grandson of Noah, on the basis of the name alone. 'What else is it', Mariana asked, 'but nonsense and error, to reduce the origins of Spain to Latin derivation and in this way tarnish its venerable antiquity with lies and nonsensical dreams as these [scholars] do?'2 His contemporary, the grammarian Bernardo de Aldrete (1565-1645), also expressed his disapproval disparaging the etymological method as a 'risky business', since placenames, like languages, were always subject to unpredictable change. ${ }^{3}$ Indeed, by the early seventeenth century doubts emerged in Spain regarding the reliability of the study of etymologies and their uses in historical writing. Detractors, like Mariana and Aldrete, condemned the practice, arguing that the corre-

1 'Lo mismo me parece ha acontecido á muchos historiadores asi de los nuestros como de los estraños: que donde faltaba la luz de la historia, y la ignorancia de la antigüedad ponia uno como velo á los ojos para no saber cosas tan viejas y olvidadas, ellos con deseo de ilustrar y ennoblecer las gentes cuyos hechos escribian, y para mayor gracia de su escritura, y mas en particular por no dexar interpolado con lagunas el cuento de los tiempos, antes esmaltallos con la luz y lustre de grandes cosas y hazañas, por sí mismos inventaron muchas hablillas y fabulas'; Juan de Mariana, Historia general de España compuesta enmendada y añadida, por el padre Juan de Mariana; con el sumario y tabla [Lat. 1592; Spa.16o1] (Madrid:Joaquín de Ibarra, 1780), vol. 1: book I, ch. viI, pp. 13-14.

2 '... porque qué otra cosa es sino desvario y desatinar, reducir tan grande antigüedad como la de los principios de España, á derivacion Latina; y juntamenta afear la venerable antigüedad con mentiras y sueños desvariados como estos hacen?' Mariana, Historia general, vol. 1: book I, ch. VII, p. 13 .

3 'es negocio lleno de riezgo, i peligro tratar desto porque se camina con solo indicios, i pruevas inciertas, dependientes de palabras tan ligeras de mudarse'. Bernardo de Aldrete, Del origen y principio de la lengua castellana, ò Romance que oy se vsa en España (Rome: Carlo Vulliet, 1606), book III, ch. III, p. 284 .

(C) VALERIA LÓPEZ FADUL, 2016 | DOI 10.1163/9789004324329_005

This is an open access chapter distributed under the terms of the CC-BY-NC-ND License. 
spondence between toponyms, like Toledo, Cordoba, or even the appellation Hispania, and the intention of their earliest makers was impossible to prove.

This represented a significant shift. Only a few decades earlier and throughout the second half of the sixteenth century, etymologies constituted an important, and hotly contested, source of knowledge about the history and culture of the Iberian Peninsula. ${ }^{4}$ The method was a serious pursuit that struck at the core of some of the most controversial aspects of Spanish history and self-understanding. Scholars in various genres used etymological derivations to further a particular understanding of their region's ancient and more recent past, especially in cases where histories were not extant or the testimonies recorded in surviving accounts were incomplete or dubious. The Basque chronicler Esteban de Garibay y Zamalloa (1533-160o), for instance, declared without a doubt in 1571 that ever since the first age of the world the founders of a region would confer upon their territories their own name. This practice, which Garibay believed was amply attested in the writings of the most ancient authorities, allowed the historian to definitively trace back, through the study of toponyms, the origins of all people. ${ }^{5}$

While the etymological approach was common, to some degree, throughout Europe - among the most famous and prolific of early modern etymologists was the Frenchman Jean Bodin (1530-96) - Spanish writers stood apart in the extent to which they sought to marshal etymologies to overcome or assimilate a problematic historical and religious heritage which threatened to relegate Spain to a lesser status among her more purely 'European' rivals. The history and languages of early modern Spain bore the indelible imprint of centuries of Arabic and Hebrew habitation. Consequently, Iberian scholars' need to grapple with the history of populations of non-Christian origins, and to weigh their future integration into an ever more repressive old-Christian mainstream cul-

4 Angus Vine, 'Etymologies, Names and the Search for Origins: Deriving the Past in Early Modern England', The Seventeenth Century, 21 (2006): pp. 1-21; also, In Defiance of Time: Antiquarian Writing in Early Modern England (Oxford: Oxford University Press, 2010); and Claude Gilbert Duboise, Mythe et langage au XVI ${ }^{e}$ siècle (Bordeaux: Ducros, 1970), p. 80.

5 'Es cosa antiquissima, comēçada dende la primera edad del mundo, y usada en estos tiempos, y continuada hasta los nuestros, poner de ordinario, o lo menos muchas vezes, los fundadores y pobladores de las naciones, provincias y pueblos, sus nōbres a las tales naciones y regiones y poblaciones, como d'esto hallamos muchos exemplos de los padres de la segunda y tercera edad del mundo;' Esteban de Garibay, Los xL libros d'el compendio historial de las chronicas y vniuersal Historia de todos los reynos de España (Antwerp: Christophe Plantin, 1571), book IIII, ch. vi, p. 95. On Garibay see: Julio Caro Baroja, Los vascos y la historia a través de Garibay (Madrid: Caro Raggio, 2002), pp. 174-89. 
ture, invested Iberian etymological histories, and the theories of origins that they sought to support, with an unparalleled and often polemical urgency.

Responding to concerns over the status of Castile within the Peninsula, the loyalty of recent Muslim and Jewish converts, and Spain's place within Europe and Christendom, Spanish intellectuals increasingly placed language at the center of a politically fraught project to 'convert' the history and geography of their homeland in ways intimately connected with the conversion of Jewish and Muslim bodies and communities to Christianity. Whether working directly under the patronage of Felipe II, or outside the confines of the royal court, Spanish scholars engaged in linguistic debates designed to reclaim the Iberian Peninsula's Basque or Hebraic origins, assert its classical heritage, and neutralize and assimilate its Arabic legacy.

To do so, they usually resorted to two interrelated methodologies for converting linguistic patrimony into proof of antiquity. The first was the analysis of place names, which required identifying their languages of origin and how they changed over time to reach their present form. The second involved establishing the relationship between the vernaculars spoken in an area with Hebrew, Greek or Latin, the three languages of the Bible. ${ }^{6}$ Each of these strategies entailed a range of possibilities, but also demanded that scholars implicitly or explicitly subscribe to, or in some instances even develop, systems of causation to account for the linguistic transformations that they were attempting to describe. These systems ranged from the paradigm of the Tower of Babel in the Book of Genesis, to theories on the cyclical rise and decline of languages, to climate and the effects of trade and political ruptures or, in some cases, a combination thereof. ${ }^{7}$

This chapter examines the range of ways in which early modern Spanish scholars like the chronicler Ambrosio de Morales (1513-91), the biblical scholar Benito Arias Montano (1527-98), the Basque lawyer Andrés Poza (1530-95), and the Arabic lexicographer Diego de Guadix (ca.1550-1615) attempted to wring historical knowledge from Iberia's etymological landscape. It focuses on their efforts to account for the seemingly ubiquitous presence of Hebrew and Arabic placenames and loan words in Spain's many territories and languages. The resolution of two problems became central to deciphering Spain's remote history and its ensuing linguistic diversity: the first was the question of what had been the Iberian Peninsula's primordial tongue, and consequently the

6 Robert H. Robins, Breve historia de la lingüistica (Madrid: Paraninfo, 1974), p. 99.

7 See Juan Manuel Lope Blanch, 'La lingüística española del Siglo de Oro', in Actas del VIII Congreso de la Asociación Internacional de Hispanistas, (coord.) A. David Kossoff et al. (Madrid: Istmo, 1986), pp. $37-58$. 
identity of its primitive inhabitants before the arrival of successive foreign conquering polities. Second, the matter of clarifying Castilian's relationship to Arabic and whether that language, and its society, had changed irretrievably as a response to the Islamic centuries.

The proliferation of linguistic histories that sought to answer these questions led many scholars to conclude, despite the increasingly influential association between language and religious identity that ultimately resulted in the prohibition of Arabic, that Spain's Oriental languages, and their traditions, could not be disregarded. How to incorporate them into a historical narrative without their religious elements became a challenge that equally concerned lexicographers, antiquarians, and forgers. Etymologies became an effective way through which humanists in an increasingly intolerant society included 'unwanted' people into their understanding of the Iberian Peninsula's past. The commitment to prove that certain toponyms derived from Hebrew or Arabic, or neither, however, would also help to bring about an unintended consequence. An accumulation of ever more detailed explanations of how and why certain toponyms related to the sacred tongue and the conflicting interpretations upon which these convoluted linguistic genealogies rested, would prompt scholars, like Aldrete, to question whether the etymological method, in any of its iterations, could serve to reconstruct ancient history.

\section{Etymologies, Origins, and the History of Languages}

Etymologies have a long tradition and underlay a wide spectrum of intellectual pursuits. The study of names played important functions in medieval and early modern mystical, exegetical, and historical writings and often fulfilled rhetorical purposes. Isidore of Seville defined etymology as 'the origin of words, when the force of a verb or noun is inferred through interpretation'. Knowing the origin of a word made it easier to understand its force, and 'one's insight into anything is clearer when its etymology is known'. ${ }^{8}$ Building on the works of Josephus, Jerome, Isidore of Seville, and significantly on the forged genealogies of Anno da Viterbo (1432-1502), sixteenth-century scholars further refined the historical and exegetical uses of etymology. Florián de Ocampo (d. 1558), for instance, infamously incorporated Viterbo's writings into his own Corónica

8 Isidore of Seville, The Etymologies of Isidore of Seville, (trans.) Stephen A. Barney et al. (Cambridge: University Press, 2010), book I, ch. 29, pp. 54-55. Also see: Frank L. Borchhardt, 'Etymology in Tradition and in the Northern Renaissance', Journal of the History of Ideas, 29 (1968): pp. $415^{-29}$. 
general de España (General Chronicle of Spain, 1543) and maintained that Spain's most ancient inhabitants originated from a grandson of Noah, Tubal. To support this and other elaborate lineages, authors like Ocampo often offered linguistic proofs. They did so by etymologizing the names of cities and towns and establishing a direct filiation between particular toponyms and their corresponding biblical or mythological founders. For example, Ocampo asserted that the region of Tudela in the kingdom of Navarra had also been established by Tubal. He arrived at this foundational hypothesis by explaining how the word had mutated. Years of use corrupted the word Tuballa to Tudela. ${ }^{9}$

Jean Bodin in his Methodus ad facilem historiarum cognitionem (Method for the Easy Comprehension of History, 1566) - one of the most influential early modern treatises on how to read and assess historical writing - exalted the value of the etymology and detailed the ways in which historians could employ this type of proof. In the ninth chapter of the Method he declared that no other question had 'exercised the writers of history more' than that of the origins of peoples. Three types of evidence, based on an awareness of the principles that governed nature and change over time, could be used to stream backwards towards origins. Chief among the three was the study of etymologies, followed by the 'the situation and character of the region', and finally, the reliability of the historian relating the conditions of previous times. ${ }^{10}$

Despite the myriad changes to which languages were constantly subjected, Bodin argued that traces of their original form always managed to endure the passing of time, the corruption prompted by the contact with other languages, and the changes brought about by climate and geography. If names preserved ancient local traditions, then those willing to investigate those traditions and collate their contents with etymological derivations could make use of the information contained in topographical names to promote their accounts of how places developed and who settled them at first. ${ }^{11}$ Names had the capacity,

Florián de Ocampo, Los cinco primeros libros de la Crónica general de España (Medina del Campo: Guillermo de Millis, 1553), book I, ch. IIII, fol. xxiiir.

Jean Bodin, Method for the Easy Comprehension of History, (trans.) Beatrice Reynolds (New York: W.W. Norton and Company, 1969), p. 334-38.

11 On the influence of Anno da Viterbo on Jean Bodin see: Anthony Grafton, 'Traditions of Invention and Inventions of Tradition in Renaissance Italy: Annius of Viterbo', in Defenders of the Text: The Traditions of Scholarship in the Age of Science 1450-1800 (Cambridge: Harvard University Press, 1994), ch. 3, pp. 76-103, p. 88; 'Method and Madness in the Ars Historica', in What was History? (Cambridge: Cambridge University Press, 2007), ch. 3, pp. 167-88. On the Reception of Jean Bodin in the Iberian Peninsula see: Martim de Albuquerque, Jean Bodin na Península Ibérica. Ensaio de história das ideias políticas e de direito Público (Paris: Fundação Calouste Gulbenkian, Centro Cultural Português, 1978). 
as Angus Vine has argued, to 'continuously transmit origins' and 'communicate between the past and the present'. ${ }^{12}$

Bodin's linguistic reasoning and reliance on the etymology as a road towards one primordial, pre-Babelian, tongue was characteristic of Renaissance linguistics. As Marie Luce Demonet and Claude-Gilbert Dubois have argued, sixteenth-century scholars were simultaneously engaged with the problem of retrieving the original language, which the majority believed to be Hebrew, and its inherent wisdom, as well as with that of explaining and coping with the diversity of idioms that existed in the world. ${ }^{13}$ Seventy-two languages appeared after the Tower of Babel, which in turn engendered many more. As chapter XI of Genesis states, before the confusion of Babylon all peoples used the same language. This language, the most excellent of all, would prevail amongst those who did not 'conspire in the deviated edification of the tower', and 'one of the just [ones] was Heber, from whom the Hebrew tongue takes its name'.14 Besides collecting linguistic information, as Conrad Gessner (151665 ) did in his Mithridates (1555), numerous scholars attempted to derive certain principles to account for the ways in which languages had mutated. ${ }^{15}$

Although early modern linguists generally limited their investigations to languages, peoples, and events deemed to have appeared within the Bible, this was not an entirely confining paradigm. The Biblical text provided few 'unambiguous statements on language' and scholars could 'speculate freely on linguistic problems despite a background of traditional Biblical lore.' ${ }^{16}$ Some writers, like the Italian linguist Celso Cittadini (1553-1627) or the aforementioned Bodin or Aldrete, attempted to explain linguistic change through

12 Vine, 'Etymologies, Names', p. 1.

13 Dubois, Mythe et langage, p. 16; Jean Céard, 'De Babel á la Pentecôte: La transformation du mythe de la confusion des langues au XvI ${ }^{\mathrm{e}}$ siècle', Bibliothèque d'humanisme, 42 (1980): pp. 577-94; Marie Luce Demonet, 'Renaissance étymologiques', in Lexique 14: L'étymologie de l'antiquité à la renaissance, (ed.) Claude Buridant (Lille: Presses Universitaires du Septentrion, 1998), pp. 57-67.

14 'Se mantuvo no obstante la casa de Heber en la que permaneció la que antaño había sido única lengua de todos. Por ello, como recordé antes, al contarse los hijos de Sem, cada uno de los cuales dio origen a un pueblo...' Juan Luis Vives, Los comentarios de Juan Luis Vives a 'La ciudad de Dios' de San Agustín, (trans.) Rafael Cabrera Petit (Valencia: Ajuntament, 2000), ch. XI, IV. See St Augustine, The City of God, (trans.) Marcus Dods (New York: Modern Library, 1950), pp. 536-37.

15 Conrad Gesner, Mithridates, (trans.) Bernard Colombat and Manfred Peters (Geneva: Droz, 2009), fol. 2v.

16 George J. Metcalf, 'Abraham Mylius (1563-1637) on historical linguistics', in On Language Diversity and Relationship from Bibliander to Adelung, (ed.) T. Van Hal and R. Van Rooy (Amsterdam, Philadelphia: John Benjamins, 2013), pp. 85-104, esp. p. 87. 
broader systems of causation combining natural and political factors. ${ }^{17}$ Etymological derivations, in their turn, could be used, as they were by the French Hebraist Guillaume Postel (1510-81) or the Dutch physician and linguist Johannes Goropius Becanus (1519-72), to advance specific agendas, including a system of beliefs or a particular theory of history that exalted the antiquity or primordial characteristics of their communities.

Explaining how and why languages change, and how this understanding could be used to account for the history of Castilian (and of Spain more generally), lay at the core of Juan de Valdés' (1509-41) well-known Dialogue on Language (1535)..$^{18}$ Although the Dialogue remained unpublished until the nineteenth century, it circulated widely in manuscript form. ${ }^{19}$ It was one of the first works to discuss the history of Castilian and its relationship with the other tongues extant in the Iberian Peninsula. ${ }^{20}$ Valdés' Dialogue reveals important questions, themes, and exegetical tools that subsequent scholars would reaffirm or challenge in their search for the origins and history of Spain's multiple languages and their speakers.

Covering topics which we would now separate out as lexicography, phonetics, and grammar, Valdés articulated a number of hypotheses on the ways in which different types of linguistic alterations took place and their relationship to broader political and social events. For Valdés, commerce and conquest were the most significant factors triggering linguistic change. He argued that the transformation of languages could occur suddenly, due to violent political ruptures, but also gradually, as a result of quotidian interactions with neighboring societies. Spain possessed such a great number of languages, Valdés argued, because it had been subject to so many different overlords across its ancient and modern history. Further linguistic mutations ensued through

17 Michael T. Ward, 'Bernardo de Aldrete and Celso Cittadini: Shared Sophistication in Renaissance Linguistic Investigation', Hispanic Review, 61 (1993): pp. 65-85; Lucia Binotti, Cultural Capital, Language and National Identity in Imperial Spain (Woodbridge: Tamesis, 2012), ch. 7 'Historicizing Language, Imagining People: Aldrete and Linguistics Politics', pp. 149-72, esp. pp. 154-55.

On the life and works of Juan de Valdés see Daniel Crews, Twighlight of the Renaissance: The Life of Juan de Valdés (Toronto: University of Toronto Press, 2008). On the Diálogo see Ignacio Navarrete, 'Juan de Valdés, Diego Hurtado de Mendoza and the Imperial Style in Spanish Poetry', Renaissance and Reformation, 28 (2004): pp. 3-25.

19 See Gregorio Mayáns y Siscar, Orígenes de la lengua española, compuestos por varios autores (Madrid: Juan de Zúñiga, 1737), vol. 1, pp. 179-80.

Manuel Taboada Cid, 'Lingüística hispánica renacentista: lenguas y dialectos en las gramáticas españolas de los siglos XVI y XVII (1492-1630)', Verba. Anuario galego de filoloxía, 16 (1989): pp. 77-95. 
trade with neighboring societies. Each of the provinces of the Iberian Peninsula continuously borrowed words and sounds from nearby kingdoms, thereby endowing each of them with its own, remarkably unique, language.

Valdés approached the controversy surrounding ancient Spaniards' original, pre-Roman tongue with ambivalence, conceding that it belonged more to the realm of history than to grammar. However, he believed that this question could be answered by considering the evidence provided by grammar alongside that rendered by history. Although many claimed that Basque was the most ancient language of the Iberian Peninsula, given its unique characteristics and the fact that foreign invaders had never managed to subdue the Basque territories, a closer reading of ancient historians led Valdés to dispute this finding. The most widespread tongue in ancient Spain, he argued, was not Basque, but Greek. The reign of Greek lasted only until the Romans conquered Iberia, at which time Latin gradually 'banished the Greek from Spain'. The subsequent invasion of the Goths further corrupted the Roman language. The use of a hybrid Latin, with elements of Greek and Gothic, lasted until the arrival of the Arabs in the eighth century. This mixed language subsequently also incorporated numerous Arabic words, because even though the kingdoms were regained, there still remained in them many Moors as dwellers that maintained their language.'21 Castilian's lexical borrowing from Arabic was extremely broad, the product of extended social and political relations with its native speakers.

Reflecting on the specific mechanics of linguistic borrowing, Valdés asserted that by establishing the categories of words that the speakers of one language borrowed from the speakers of another, an observer could determine the nature of the social, political, and/or commercial dealings which these societies shared. Thus one might work backwards from lists of the Arabic words which had managed to infiltrate the Castilian lexicon in order to determine what kinds of things the Arabs had introduced into the Peninsula. Valdés remarked that 'even though many things that they name with Arabic words have equivalents in Latin', usage made Castilians prefer the Arabic word to the Latinate one. For this reason people called rugs alfombras rather than tapetes, opting for the Arabic derivative over the Latin. Valdés maintained that even though Castilian had appropriated numerous words from Arabic, Latin 'was still the main pillar of the Castilian language.22 Linguistic borrowing, Valdés

21 Juan de Valdés, Diálogo de lengua, (ed.) José Enrique Laplana (Barcelona: Crítica, 2010), pp. $130-35$.

22 'todavía la lengua latina es el principal fundamento de la castellana'; Valdés, Diálogo de lengua, p. 139. 
emphasized, regardless of its particular dynamics or motivations, was inevitable, governed by the ebb and flow of usage, and devoid of moral or religious connotations.

Valdés' conclusions betray a fundamental assumption about the causes of linguistic change, one which he shared with Bodin (and many other contemporaries): namely, that the history of a spoken language parallels in fundamental ways the lived experiences of its speakers and, as such - because some of a people's original qualities always endure in their languages - it can be used to reconstruct that society's history.

Valdés' selection of Greek as Iberia's primordial language, his omission of Hebrew, and his choice to set the arrival of Arabic late in the history of Spain, can be attributed at least in part to his reading of ancient historians like Pliny and Strabo, who took careful note of the Greek colonies scattered throughout the Peninsula's Eastern coast. But it can also be attributed to his humanist prejudice. Valdés sought to emphasize Spain's connection to the Greek tongue, since this language possessed expressive capabilities and qualities that exalted the genealogy of Castilian and of Spain. His linguistic hierarchy highlighted Spain's origins in the classical world centuries before the Romans entered the Iberian Peninsula's through its eastern shores. ${ }^{23}$

\section{Hebrew, Basque, and the Search for Spain's Primordial Tongue}

Valdés' discussion demonstrates the existence of multiple traditions regarding Spain's original language. A number of Basque and non-Basque scholars contended that this tongue occupied the primordial position. Others were more skeptical as to whether the truth on the matter could even be unearthed. For the antiquarian Ambrosio de Morales, the first language of Spain was impossible to determine, because in the time of the Romans, when the earliest surviving histories appeared, the natives of those kingdoms already spoke very different languages. Seneca, Cornelius Tacitus, and Strabo, when writing about the languages of the Iberian Peninsula, asserted that the people of those lands did not use one single language, but rather each possessed their own natural tongue. The archbishop of Tarragona Antonio Agustín (1516-86) was of the same opinion, regarding the Basque hypothesis as untenable on the grounds

23 Werner Bahner, La lingüística española del Siglo de Oro. Aportaciones a la conciencia lingüística en la España de los siglos XVI y XVII (Madrid: Ciencia Nueva, 1966), pp. 63-72. 
that neither books nor any other written memories survived in that language. It was, therefore, impossible to prove its antiquity. ${ }^{24}$

Morales' skepticism on whether the first language of Spain could ever be retrieved, did not preclude him, however, from participating in discussions on the origins of the label 'Spain', or Hispania, itself, a topic which had been in dispute ever since the seventh century, when Isidore of Seville (ca. 56o-636) had traced it to the word Hispanus, a corruption of the name Hispalus, the legendary founder of the city of Hispalis (now known as Seville). ${ }^{25}$ The majority of authors who endeavored to decipher the identity of the Peninsula's first settlers contended with this issue. In many instances the interpretations that they offered served as a cornerstone to their broader theory of origins and as a pivotal moment explaining Spain's subsequent development.

Morales' favourite theory as to the origin of Hispania, for example, was that advanced by his contemporary Diego Hurtado de Mendoza (1503-75). Hurtado de Mendoza believed that he had located the most reliable tradition regarding the true origin of Spain's name among the collection of Greek manuscripts which he had carefully amassed while serving the Emperor Carlos V as his ambassador to Venice in the 1540s. Pliny and Varro had narrated in their Latin works the story of the famous Greek captain Dionysus, also known as Bacchus, who travelled to Spain to further his conquests. Upon his return to Greece he granted authority over the recently subdued areas in Iberia to one of his captains, a commander named Pan. The ancient Greek article (-is), attached to the commander's name to denote dominion over his colony, transformed the word to Ispanos or 'that which is of Pan'. Morales was enthusiastic in his embrace of Hurtado de Mendoza's theory, noting that his counterpart was the first scholar who possessed both the ingenuity and the sources to prove this connection. Although Morales' uncertainties about the lack of primitive documents prevented him, unlike Valdés, from definitively setting Greek as most ancient language of Spain, his selection of this etymology did allow him to highlight the Greek settlement as the formative moment in shaping the character of the Iberian Peninsula's primitive and future inhabitants. ${ }^{26}$

Morales' and Valdés' preference for the Greek theory of origins, however, was not destined to be the final word on the subject. For many, as Ocampo's controversial genealogies had shown, the postdiluvian and most ancient

\footnotetext{
24 Mayáns, Orígenes de la lengua, p. 49.

25 Isidore of Seville, The Etymologies, book IX, ch. 109.

26 Ambrosio de Morales, Las antigüedades de las ciudades de España que van nombradas en la corónica con las averiguaciones de sus sitios y nombres antigüos, (ed.) Enrique Florez, 2 vols. (Madrid: Benito Cano, 1792), vol..1, pp. 112-113.
} 
dwellers of Spain had to be traced directly to Noah's progeny. The problem became, then, determining what language the Patriarch's descendants had spoken and whether they had maintained their speech intact upon reaching Spain. The Basque hypothesis, though popular, had to compete with the increasingly appealing idea that the first language of the Peninsula had been Hebrew.

In his work on the city of Cordoba, the painter Pablo de Céspedes (d. 16o8) explicitly challenged the hypothesis that the descendants of Noah that reached Spain after the Flood spoke Basque. Noah's descendants, he clarified, must have spoken Hebrew, the first language of mankind. They had settled many urban centers throughout Spain and the most notable among them was Cordoba. ${ }^{27} \mathrm{~A}$ correspondent and friend of Arias Montano and Aldrete, Céspedes, who became in the later years of his life a canon in Cordoba's cathedral chapter, applied his linguistic and antiquarian erudition to explicate the most remote origins of his birthplace. Employing a strategy similar to Bodin's, Céspedes offered both etymological and archeological evidence that linked Cordoba to ancient Jews.

Céspedes claimed, through an elaborate succession of etymologies, that Córdoba was properly interpreted not as a Latin or Greek name, but rather as a derivative of Hebrew. Freeing the toponym from the phonetic distortions wrought by the passage of time, and displaying an impressive knowledge of sacred history and texts, Céspedes reduced the word to two 'Hebrew' syllables, kar and daba. Together, he argued, these meant 'plain of strength, of fertility, of richness, of beauty, of fecundity, and virtue'. The Hebrew word, with the expressive power that characterized the holy language, had the ability to convey the main properties of the city. The word contained multiple chains of signification that alluded to Cordoba's fertility and temperate climate. These features allowed the city to nurture countless virtuous men and women and to encourage the blossoming of philosophy, medicine, and the other arts. ${ }^{28}$

27 Francisco Javier Perea Siller, 'Pablo de Céspedes (1548-1608), argumentación lingüística y legitimación histórica', in Sociedad Española de Historiografía Lingüística. Congreso $\left(3^{\circ}\right.$ 2002. Vigo), (ed.) Miguel Ángel Esparza Torres et al. (Hamburg: Buske Verlag, 2002), pp. 641-52. On the life of Pablo de Céspedes, see Francisco M. Tubino, Pablo de Céspedes: obra premiada por voto unánime de la Academia de Nobles Artes de San Fernando en el certamen de 1866 (Madrid: Manuel Tello, 1868).

28 Jesús Rubio Lapaz, Pablo de Céspedes y su círculo. Humanismo y contrarreforma en la cultura andaluza del renacimiento al barroco (Granada: Universidad de Granada, 1993), p. 315. Also see: Mercedes García-Arenal and Fernando Rodríguez Mediano, 'Les Antiquités hébraïques dans l'historiographie espagnole à l'époque moderne', in Dix-septième siècle, 66 (2015): pp. 79-91, esp. pp. 81-83. 
The toponym was most likely reused by Greek and Latin geographers, who routinely adopted the preexisting names of the provinces where they settled, changing the words slightly to pronounce them more comfortably in their own language. It was no accident, according to Céspedes, that classical authors like Strabo and Virgil described the city using the same succession of adjectives implied in the Hebrew etymology. This meant that they must have learned at some point from the local inhabitants the meaning of the native appellation. Céspedes imagined the Roman authors following the same procedures as contemporary crown officials who conducted the royal censuses of the Relaciones Topográficas, querying the local inhabitants about the names of their towns and their traditions. ${ }^{29}$ Like Bodin, Céspedes sought to connect the ancient foundation of Spain to the descendants of Noah and to primitive Jews, from whom all people descended.

Céspedes' contemporary Benito Arias Montano also believed that the multiplicity of such 'Hebrew' toponyms scattered throughout the Iberian Peninsula could only be explained by the arrival of Jewish settlers in ancient times. This naturally included the name of Spain. Arias Montano proposed that Hispania or España was not a corrupted Greek word; rather, it originated in the Aramaic Spamia, a placename found in the Aramaic paraphrase, or Targum, of the biblical book of Obadiah. Adopting a line of argument common in Sephardic Jewish commentaries, Arias Montano used this reference to Spamia, the supposed destination of one of the several Israelite diasporas described in the Old Testament, to claim that Jewish settlers had known and inhabited many provinces of Spain in antiquity, buttressing his claim by identifying numerous Hebraic toponyms scattered throughout the Iberian Peninsula. ${ }^{30}$

In his Commentaria in duodecim prophetas (1571), however, Arias Montano opted for a chronology at variance with that of Céspedes. For Arias Montano, the ancient Hebrews who settled some of Spain's most distinguished cities came with the Babylonian king Nebuchadnezzar II after the destruction of the temple in Jerusalem. ${ }^{31}$ As Dominique Reyre has argued, Arias Montano's etymological exercises, lifted from medieval Jewish commentaries, aimed to show that the Jews that settled these primitive communities had arrived in the

\footnotetext{
29 On the Relaciones Topográficas see Alfredo Alvar Ezquerra (ed.), Relaciones Topográficas de Felipe II. Madrid (Madrid: CsIC, 1993).

30 See Chapter 1 in this volume by Adam Beaver, as well as Dominique Reyre, 'Topónimos hebreos y memoria de la España judía en el Siglo de Oro', Criticón, 65 (1995): pp. 31-53, esp. p. 33; F.J. Perea Siller, 'Benito Arias Montano y la identificación de Sefarad, exégesis poligráfica de Abdías 20', Helmántica Hebraica, 51 (2000): pp. 199-218. 
Iberian Peninsula at least five centuries before the birth and death of Christ. Hence they and their descendants were exempt from deicide. ${ }^{32}$

For Arias Montano, moreover, the Old Testament offered etymological hints about the New World as well as the Old, foreshadowing, the discovery of the Americas. Arias Montano and his contemporaries scoured the Bible in search of toponyms found in the New World and identified certain places in the text, with what they believed to be their American equivalents. Luis de León (152791), among others, recognized the Yucatán Peninsula with the Yoqtan of Genesis (the second of the sons of Eber) and the regions that comprised Peru with the lands of Parvaim, from where King Solomon's gold emanated. ${ }^{33}$ In his De antiquitatibus Novae Hispaniae (Antiquities of New Spain), the natural historian Francisco Hernández (1514-87), after consulting the writings of the Franciscan missionaries catechizing in Mexico, summarized the controversy cautiously. Some believed that the natives of Mesoamerica came from Palestine and that they originated in the ten tribes of Salmanasar, as the Book of Kings narrated, more that 2,200 years ago. Even if this conjecture appeared unlikely or untrue, Hernández advised his readers to consider the reasons that made the interpretation plausible, or at least worthy of consideration. Among his most powerful arguments was the reference to etymologies, since in New Spain there were 'not few words that were either Hebrew [in origin] or very similar to them, as if they originated from them. ${ }^{34}$

The Basque lawyer Andrés de Poza (1530-95) approached the problem of Spain's original language using a similar method as that of Céspedes and Arias Montano but reached different conclusions. ${ }^{35}$ When reading the works

$3^{2}$ Reyre, 'Topónimos hebreos', p. 33.

33 Genesis 10:26. See Emilia Fernández Tejero and Natalio Fernández Marcos, 'Scriptural Interpretation in Renaissance Spain', in Hebrew Bible/Old Testament: The History of Its Interpretation, Vol. II: From the Renaissance to the Enlightenment, (ed.) Magne Sæbø (Göttingen: Vandenhoeck \& Ruprecht, 2008), p. 241.

34 'Hay quienes aseguran que todos estos vinieron de Palestina, atravesando un angosto mar, de las diez tribus de Salmanasar, rey de de los Asirios, condujo cautivos a Asiria, reinando en Israel Oseas y en Jerusalén Ezequías, como se lee en el libro cuarto de los Reyes, cap. decimoséptimo hace más de dos mil docientos ... En tercer lugar los nombres, no de otra manera que entre los hebreos, se imponían por deliberación del consejo y sin algún ethimo'; Francisco Hernández, 'De antiquitatibus novae Hispaniae, Antigüedades de la Nueva España', in Obras Completas, (trans.) J. García Pimentel (Mexico: UnAM, 1984), vol. 4, p. 118. See Guiliano Gliozzi, 'Gli Ebrei nel Nuovo Mondo', in Adamo e il Nuovo Mondo. Las nascita dell'antropologia come idologia coloniale: dalle genealogie bibliche alle teorie razziali (1500-1700) (Florence: La Nuova Italia Editrice, 1977), pp. 49-110.

'Pues estos Griegos como vinieron a las Españas fundaron luego en ellas una muchedumbre de poblaciones, de que aun oy dia nos queda el rastro claro, digo claro, porque los 
of Bodin, Poza had come across a different Greek interpretation of Hispania. Bodin argued that the term signified 'land scarce in towns', and that the Greeks used the appellative to describe the land of the Hiberians or Heberi, whose 'language differed only a little from Hebrew' ${ }^{36}$ If the Greeks had really assigned the name to these territories, then Spain must have been devoid of very large settlements at the time of their arrival. However, Poza noted, this was not true in the era of the Carthaginians, nor the Romans. The word 'Spain', then, must have predated the arrival of Greek settlers in the Peninsula, and must signify something else altogether. Poza solved this problem by pointing to the phonetic similarities between España and the Basque word Esbana, meaning 'land of good lips and tongue'. Insisting that the Basques must have been the Peninsula's most ancient inhabitants, Poza defended the appropriateness of his etymology by noting that the Spaniards naturally possessed great eloquence.'37

While for Poza, the desire to prove the supposed primacy of Basque among the Peninsula's ancient languages effectively ruled out the Hebraic theories of Arias Montano and Céspedes, other authors found imaginative ways of reconciling these competing linguistic genealogies. Esteban de Garibay y Zamalloa argued that Basque descended directly from Hebrew, while still claiming that it was also the source language from which Castilian emerged. To do so, he established a filiation between Basque and Hebrew words and then proceeded to demonstrate that Castilian words derived from Basque. This contradicted elements of Poza's Basque-ophile approach, which aimed to show that Basque was one of the seventy-two languages that appeared after the Tower of Babel, but not that it was the source of Castilian. That language came with the Romans centuries later. ${ }^{38}$

The main evidence to support Poza's history was, like that of his antagonists, etymological. Poza contended that the suffix briga, which finalized the names of some of Spain's oldest cities, was a Basque word. The word 'Cantabria', for instance, stood for Cantabriga. This name was a composite of brigo and canto. The first word meant abrigo (shelter and company), and it was from where the Castilians took the verb abrigar (to shelter). From this meaning it can be deduced that the ancients called brigas the settlements that were fenced or

mismos nombres lo manifiestan'; Andrés de Poza, De la antigua lengua, poblaciones, y comarcas de las Españas, en que de paso se tocan algunas cosas de la Cantabria (Bilbao: Mathías Mares, 1587), fol. 22r.

$36 \quad$ See Bodin, Method, p. 359.

37 Poza, De la antigua lengua, fol. 22r.

38 Garibay y Zamalloa, Los XL libros d'el compendio historial de las chronicas y vniuersal Historia de todos los reynos de España (Antwerp: Christophe Plantin, 1571), book V, ch. IIII, pp. 125-33. 
sheltered, because these provide shelter or abrigo from those who live in the roughness of the cliffs, edges, and mountains of these regions'. Ocampo confirmed that briga was part of the ancient language of Cantabria in his Chronicle, theorizing that the Roman emperor Vespasian had established a city in Spain on the edges of the sea of Biscay named Flavio briga. This was 'a combination of his name, with the speech of the region, in which towns were referred as to as brigas. ${ }^{39}$

Basque's expressive capabilities marked it as one of the seventy-two languages that emerged immediately after the confusion at the Tower of Babel, since these ancient tongues possessed special powers. 'An excellent language', Poza reasoned, is 'one in which the names themselves teach their own cause, [or] the definition and nature of the thing named'. He invoked Plato's Cratylus to argue his case. Languages could only be described as 'elegant, substantial, and philosophical' if their names were able to transmit the qualities of the objects that they signified. Languages that were not part of the seventy-two, but were 'rather mestizos (mixed) and imperfect', possessed names 'without any mystery', and thus were conventional. Poza's use of the word mestizo is telling, for he also summoned images from the New World to support his linguistic genealogy. 40

Many ancient Basque and Hebrew toponyms remained dispersed throughout Spain even though speakers of these languages no longer resided in their former lands or had abandoned their first idioms in favor of others. The reasons for this were identical, Poza hypothesized, to what was occurring to the Spaniards that established themselves in the Indies. The Spanish conquerors, even though they were mainly speakers of Castilian, still referred to the provinces of the New World 'with their first names in the Indian languages'. Mexico, Peru, Chile and Cuzco were all indigenous place-names. Poza believed that these names were so resilient to the passing of time, and even to the demise of their native inhabitants, because of their antiquity and their language of origin: the original, shared tongue of mankind.

Poza, De la antigua lengua, fol. 3 or.

40 'Tienese por lengua excelente la que en los mismos nombres enseña así la causa de ellos como la naturaleza y definición de la cosa que se nombra, de la cual consideración resultó la disputa de Platón en Cratilo sobre si los nombres eran puestos a caso o divinamente, porque en las lenguas que se pueden decir elegantes, sustanciales y filosóficas, hallaremos no solo la demostración, más también el sentido y definición de las cosas; pero en las que no son tales, sino mestizas e imperfectas, no hallaremos más de solo los nombres, sin tener más misterio de que la tal cosa fue llamada así, en el cual caso podremos decir que la tal lengua fue y es casual del todo'; Poza, De la antigua lengua, fol. 3or-v. 
Although he did not identify the specific settlers that brought the pre-Babelian language to the New World, his chronology indicates that the Indies were settled by the survivors of the Flood. ${ }^{41}$ Moreover, the perspective offered by the New World provided the Basque scholar additional evidence to support his etymological reasoning. The many social, religious and demographic transformations brought about by the Spanish presence in the Indies, which the contemporary scholar could witness with his own eyes, were living examples of what must have happened centuries before in the Old World. Aldrete, when composing his history of the Castilian language, would also resort to similar analogies to think about the temporal conditions regulating a society's capacity to adopt a foreign tongue and the swiftness with which this process could take place.

Poza's establishment of Basque as the first general language of Spain, as opposed to Greek, Latin, or Hebrew had further implications. His linguistic history stressed an autochthonous genealogy; one connected to the events at the Tower of Babel, permanent since its inception, and immune to the changes imposed by the conquering polities that settled Spain, most notably the Muslim overlords that ruled of parts of the peninsula for almost eight hundred years. By making Basque one of the seventy-two languages Poza could also, unlike Garibay, free himself from having to clarify the relationship between Basque and Hebrew words. The sudden ruptures brought about at Babel were enough to explain the linguistic divergences. Céspedes and Montano, in contrast to Poza, sought to stress the continuities with the Biblical past and in this manner vindicate Spain's Jewish heritage.

\section{Arabic and the History of Spain}

The pace and extent of linguistic loss or corruption attributable to conquering overlords that so much interested Valdés also became important themes in the discussion of Arabic's presence in the Iberian Peninsula. Various interpretations emerged to explain the history of this Oriental language, its relationship

$41 \quad$ '... con el nombre que sus moradores y pobladores le avían impuesto, así como ahora nuestros Españoles en las indias, sin embargo de su lengua Castellana, todavía nombran las provincias con sus nombres primeros de la lengua Indiana, Mexico, Peru, Chile, Cuzco... De suerte que ya por este exemplo se entenderá la causa, porque los nombres de los Reyes, ciudades, y poblaciones que fueron fundadas en aquellos primeros siglos más allegados al diluvio, todos ellos son de dicha lengua primera general que se hablava por el mundo antes de la confusión de Babylonia, lo qual hallaremos muy cierto acá en nuestra España en los nombres siguientes'; Poza, De la antigua lengua, fol. $9 \mathrm{r}-\mathrm{v}$. 
to Islam, and its seemingly ubiquitous influence over many of the sounds and verbal forms of Castilian. The presence of Arabic in Spain, like that of Hebrew, offered numerous conceptual problems and possibilities. Some scholars, like Morales, struggled to develop a new interpretive framework for the study of antiquity, one that could expand to include Arabic and Islamic sources alongside the more conventional Greek and Roman sources familiar to most Renaissance antiquarians. Morales was keenly aware of how profoundly the Arabs had transformed Spain's landscape. Other men of letters, more pressingly, struggled to defend the position and trajectory of Arabic speaking Christian communities, their religious commitments, and their customs from increasingly restrictive legislation. Indeed by 1567 , Moriscos were already forbidden to write or speak Arabic, ordered to learn Castilian within three years, and denied the use of Arabic surnames, clothing, baths, and any other distinctive markers.

Many scholars, like the Valencian chronicler Rafael Martí de Viciana (150274), condemned the use of Arabic in Spain and lamented the debt which Castilian speakers owed to what he considered to be an infidel tongue. ${ }^{42}$ In his Libro de las alabanças de las lenguas hebrea, griega, latina, castellana, yvalencia$n a$ (Book of the Praises of the Hebrew, Greek, Latin, Spanish and Valencian Languages, 1574) Viciana's principal goal was to prove the nobility of the Valencian language. ${ }^{43}$ Viciana believed that Latin was the mother of both the Valencian and the Castilian languages. Castilians, because of their dealings in war and peace with the 'Hagarenes' (that is, Muslims) introduced many Arabic words into their language. For Viciana this was regrettable and the result of Castilian neglect for 'hav[ing] allowed for the loss of their own and natural words, adopting strange ones', especially from this enemy tongue. This was all the more reprehensible since there were many wise men in Castile who could have turned to the Latin language, or to Greek or Hebrew, to enrich their vocabulary. ${ }^{4}$

42 On the life and works of Martí de Viciana, see Sebastián García Martínez, 'Estudio preliminar', in Rafael Martí de Viciana, Crónica de la ínclita y coronada ciudad de Valencia (Valencia: Universidad de Valencia, 1983), vol. 1, pp. 24-222.

43 Rafael Martí de Viciana, Libro de las alabanças de las lenguas hebrea, griega, latina, castellana, y valenciana. Copiado por Marin de Viziana y consagrado al Ilustre Senado de la Inclyta y coronada ciudad de Valencia (Valencia: J. Navarro, 1574).

44 '... por cierto que es lástima ver que en la lengua Castellana aya tanta mixtura de términos, y nombres del Arávigo: y a les venido por la mucha comunicación q por muchos años han tenido en guerra y en paz con los Agarenos. Y hanse descuydado los Castellanos, dexando perder los propios, y naturales vocablos, tomando los estraños: y desto rescibe la noble lengua castellana no poco si no muy grande perjuyzio, en consentir que de la más de cevil 
Valencian, according to Viciana, did not engage in this irresponsible borrowing even though 'in the kingdom of Valencia two thirds [of the people] were Hagarenes that spoke Arabic and to this day one-third are converted [Muslims] who still speak Arabic'. Viciana asked his reader to consider the fact that, unlike Castilian, 'never has the Valencian language taken ... any Arabic word'; 'on the contrary, the Arabic language being such an enemy of Christianity, it abhors it'. Those residents of Valencia that had converted to Christianity from Islam, still refused to abandon Arabic Castilian, even fifty years after their baptisms. Whenever the authorities pressured these converts to speak Valencian, Viciana recalled, they responded to the affront by questioning the authorities' intentions: 'Why do you want us to abandon the Arabic language? Is it because it is evil? And if it is evil, why do the Castilians speak it mixed in with their language? Leave us our language and we will leave it little by little.45 Implicit in this rebuttal was the notion that Castilian was capable of seamlessly incorporating Arabic words into its lexicon because the Arabic language was separable from the religion of Islam.

Viciana believed that this separation was impossible. To make matters worse, Castilian's borrowing from Arabic was so extensive, Viciana noted, that even all of the main rivers of the region, such as the Guadiana and the Guadalquivir, retained their Arabic names even after Christians recovered the territories. Valencian, in contradistinction to Castilian, preserved its proximity to Latin and borrowed words exclusively from its mother tongue. Viciana included tables demonstrating that Valencian words were closer to Latin in form and meaning than were Castilian ones. For Viciana, Castilian should be purified of its Arabic components. Castilian men of letters henceforth should leave behind the usage of ignorant people and direct the growth of their language by selecting new words solely from Latin, Greek, or Hebrew, the tongues

y abatida lengua Aráviga tome vocablo ni nombre alguno pues en Castilla ay millares de Varones sabios, que en lugar de los Arávigos podrían hallar vocablos propios a qualquier cosa'; Viciana, Libro de la alabanças, fol. b5v.

45 'Y conforme a lo dicho lo hallaran en la lengua Valenciana, que por más que en el Reyno de Valencia havía dos tercios de Agarenos que hablavan Arávigo: y en esta era un tercio de convertidos que hablavan Arávigo, jamás la lengua Valenciana ha tomado, ni viado palabra alguna Aráviga: antes por ser el Arávigo tan enemigo del Christiano le tiene por muy aborrecido. Son estos conversos de la secta Mahomética a nuestra Sancta Fee Cathólica tales, que al cabo de cincuenta años que son baptizados jamás se ha podido acabar con ellos que dexen el Algaravía, y hablen lengua Valenciana y cuando mucho los apretamos mucho responden algunos de ellos Porque quereys que dexemos la lengua Aráviga? Por ventura es mala? Y si es mala porque la hablan los Castellanos mezclada en su lengua? Dexen ellos nuestra habla y nosotros la dexaremos poco a poco'; Viciana, Libro de las alabanças, fol. A6r. 
sanctified by the Bible. This proposition differed significantly from Valdés' understanding of both linguistic borrowing and the setting of a language's standard on the basis of usage.

Ambrosio de Morales' surveys of Castile's countryside, similarly, led him to recognize that the omnipresence of Arabic toponyms made the reconstruction of Spain's Roman history challenging. ${ }^{46}$ This was especially true about the names of towns, rivers and mountains, which had been corrupted or completely effaced by the Arab conquerors.

Morales cited the surviving histories Isidore of Seville and Ildefonsus (d. 667), authors who were 'grave and trustworthy' and who had lived in the period between the Romans and the arrival of the Muslims, to demonstrate that neither the Goths nor any other of the conquering nations that invaded Spain after the fall of the Roman Empire had significantly transformed the names of the Iberian Peninsula's cities or major land formations until the arrival of the Arabs. It was then when the most significant mutations took place and cities and entire regions acquired entirely new denominations. ${ }^{47}$

Like many other historians and antiquaries of his generation, Morales was concerned about the discontinuity in Spanish history caused by the Islamic conquest. He tried to overcome this discontinuity - so evident in the sudden change of the names of many places - by compiling a study of Las antigüedades de las ciudades de España (The Antiquities of the Cities of Spain, 1575). This problem, combined with his desire to elucidate the reasoning behind the study of antiquities, compelled Morales to formulate thirteen methodological considerations that the student of Spanish stones, statues, coins and

46 On the life and career of Morales, see Katherine Elliott van Liere, 'The Missionary and the Moorslayer: James the Apostle in Spanish Historiography from Isidore of Seville to Ambrosio de Morales', Viator, 37 (2006): pp. 519-43; Richard Kagan, Clio and the Crown: The Politics of History in Medieval and Early Modern Spain (Baltimore: Johns Hopkins University Press, 2009), pp. 106-14; Sebastián Sánchez Madrid, Arqueología y humanismo, Ambrosio de Morales (Cordoba: Universidad de Córdoba, 2002); and Enrique Redel, Ambrosio de Morales, estudio biográfico (Cordoba: Imprenta de El Diario, 1909).

'Mas si lee á San Isidoro y á San Ildefonso en sus Historias: y mira los Concilios de que aquellos tiempos, y lo que dellos escrive el Arcopispo don Rodrigo y la Historia general también: en estos authores que son graves y fidedignos, no hallará mudado nombre ninguno de los q los Romanos tenian puestos en las ciudades de España, ó de los que ellas antes tenían. Los Alarabes fueron los que hizieron después este trueque, q hasta allí no le auia auido'; Ambrosio de Morales, Apologia de Ambrosio de Morales, con una información al Consejo del Rey Nuestro Señor, hecha por su orden y mandamiento en defensa de los Anales de Geronymo Çurita (Zaragoza: Colegio de S. Vicente Ferrer, Juan de Lanaja y Quartanet, 1610), fol.6v. 
inscriptions, had to bear in mind when performing research. ${ }^{48} \mathrm{~A}$ companion volume to the author's continuation of Ocampo's Corónica, the Antigüedades sought to address the technical aspects of the study of Roman antiquities that Morales had omitted from the Corónica general so as to not bore or distract his eager readers from the narrative of rulers, wars and religious events that formed the spine of this official work. ${ }^{49}$

The Discurso began with a disclaimer over the kinds of knowledge that antiquarian research could yield. The reason for this was that the antiquities of Spain were 'buried in the darkness of old age and oblivion', given the numerous invasions that the Iberian Peninsula had suffered, and 'when reason reaches the [form] of a good and possible conjecture, not more is possible nor should be expected'. Morales would assemble evidence from diverse sources and combine them to produce probable conjectures about Spanish cities and towns that had disappeared, or became new places altogether, in the wake of the Islamic conquests. The evidence offered by linguistic research, in this same manner, offered plausible but not definitive proof. Etymology was often a step towards greater certainty about the foundation of a settlement, but could not serve on its own as proof of origins. ${ }^{50}$

In his eighth consideration Morales addressed his use of language specifically. The names that cities once had, and the ones that they currently possessed, could also serve to establish correspondences between the towns recorded in Ptolemy, Pliny, or Strabo and their current forms. Morales could reconstruct an ancient name by detecting phonetic similarities between the modern word and the ancient one, like the example of the ancient city of Larissa, a small expanse of land with a single house and no surviving antiquities known as Carixa in modern times. He could also divine the reasons for the name's phonetic change. Finally, he could study the Arabic etymology and compare its meaning with the actual formation or landscape in question, as in the case of the Guadalquivir (big river valley), which was an apt descriptor for the waterway and the surrounding territories that the ancients knew as the Betis.

The Moors, Morales explained, changed many of the names of Spain. He elaborated extensively on some of these appellatives' etymologies. Almagro, for instance, 'a principal town and head of the fields of Calatrava' was named in this way because in Arabic it means 'acid water, which is true about almost all of [the water] of that place'. They called the emblematic town Alcántara,

48 Morales, Las antigüedades de las ciudades, vol. 1, p. 2.

49 Morales, Las antigüedades de las ciudades, vol. 1, p. lxxvii.

$50 \quad$ Morales, Las antigüedades de las ciudades, vol. 1, pp. 2-3. 
the same Extremaduran locale 'that gives its name to the Order', because in their language it means 'bridge', and there is a wonderful bridge in that region. Many smaller locales between Alcalá de Henares and Guadalajara likewise possessed Arabic names 'that very much agree with the places or other properties of the land'. Many other examples supported the appropriateness of the Arabic toponyms. Guadalajara means 'river of stones' and the Henares River, when it crosses that area, is full of rubble and stones. The dwellers of the region were famous for their butters made with goat's milk. These were specially crafted in a place called Irepar, which in Arabic means 'milk or fat of goat'. The town of Buje, close to Meco, is deep in a valley between hills, and Buje means hills. Likewise Benalque means house of wine and, as was to be expected from its name, was a place where much wine was made. Morales learned some of these Arabic etymologies from his friend and correspondent Francisco de Medina Mendoza (1516-77), whom he described as 'a principal man of Guadalajara'.51 Medina had become blind, yet, Morales claimed, 'all he lost in sight, he gained in his wonderful memory' ${ }^{\prime 2}$

51 Morales, Las antigüedades de las ciudades, vol. 1, pp. 80-82.

$5^{2}$ 'Los Moros tambien hiciéron muchas destas mudanzas en España por manifiestas ocasiones. Y aunque desto puede haber infinitos exemplos, yo pondré mas de los que supiere. A Almagro, villa muy principal y cabeza del campo de Calatraba, le pusiéron ese nombre que en su lengua quiere decir, agua agra qual es casi toda la de aquel lugar. Tambien llamáron Alcántara al insigne lugar de Estremadura, que da nombre á la Orden, y en su Lengua quiere decir puente, por la maravillosa que allí (según se ha visto en la Corónica hay... De la misma manera muchos destos lugarejos que están aquí entre Alcalá de Henares y Guadalaxara y por ahí cerca, tienen los nombres Arabigos muy conforme á los sitios, ó a otras propiedades de la tierra. Guadalaxara, rio de las piedras quiere decir en Arábigo, y el río de Henares por allí va muy pedregoso. Y de Caraca mudaron los Moros este nombre á su modo. Las mantequillas de Guadalaxara son muy celebradas, y no se pueden hacer sino de leche de cabras, y no se hacen sino en solo un lugar junto aquella ciudad, llamado Iriepar, que en Arábigo quiere decir leche ó manteca de cabras. Meco quiere decir pelado como lo es todo el campo de los rededores deste lugar. Bujes está junto de Meco metido en un valle entre unas cuestas, y Bujes quiere decir entre cuestas. Benalaque quiere decir casa de vino, y es lugar donde se coge mucho, y Alhobera que está allí cerca es muy fértil de pan, y el vocablo Arábigo significa Alholi de trigo. Algunas de las interpretaciones destos nombres Arábigos las notó muy bien, y me las comunicó Francisco de Medina de Mendoza hombre principal en Guadalaxara, y que en la noticia de la historia de Castilla desde el Rey don Fernando Primero acá sabe tanto como otro qualquiera, que con mucha curiosidad y particularidad la haya aprendido. De lo qual puedo yo ser muy buen testigo, como quien cada dia lo goza y lo experimenta en la mucha amistad y comunicación que con él tengo. Y como ha muchos años que cegó, todo lo que le falta de la vista, ha acrecentado en la memoria que tiene maravillosa. Sin estos nombres se podrían traer muchos lugares que tienen mudados los nombres por algunas ocasiones, como conjeturabamos 
Morales' main concern was to recover Roman antiquities from the layers of darkness that the Muslim presence imposed upon them. There is recognition in his method, however, that Arabic was a language that had to be reckoned with and incorporated into the study of Spain's and in particular Castile's history. In his case, Arabic served mainly as a useful tool to stream backwards towards other more acceptable origins, but on occasion this led him to admit the deliberateness and appropriateness of the Arabic language in describing the landscapes on which infidel Muslim overlords also set new and meaningful names.

Some cities like Morales' beloved Cordoba even possessed an extensive Muslim patrimony that amplified their Roman legacy. ${ }^{53}$ When Morales described the fertility and beauty of Cordoba, he emphasized, as Céspedes did, its temperate weather. Cordoba possessed magnificent monuments such as the 'very religious monastery of the discalced Franciscans named Arrizafa, which in Arabic means royal orchard; and this is a place of enjoyment and freshness that very well honors its name. ${ }^{54} \mathrm{He}$ claimed that it was no wonder that when the Arabic Captain Muza, a reliable witness on account of his stature, left the city after the Christians conquered it, the Muslims could do nothing more than lament the terrible loss. ${ }^{55}$

The city's fertility and favorable landscape provided a propitious environment for the flourishing of men of great intelligence and talent, regardless of their religious commitments. Cordoba was the setting where numerous martyrs immolated themselves in defense of their faith in the centuries following the Islamic conquest of 711 . The Holy martyr Eulogius compiled their lives as a testament to their unyielding Christian faith. The landscape had positive effects even on the infidels, enabling the famous philosopher 'Averroes, and with him Abezoar, Rasis, Abenragel, and many others' to achieve great things. Morales conceded that 'even though they were Moors, they were born in Cordoba and the fact that they were infidels does not take from them their greatness and high being in their natural goodness. ${ }^{\prime 6}$ Before 1609 , when, as

que podía acontecer en Porcuna, segun nos lo mostraba aquella su piedra antigua, como muchas otras dellas nos enseñan, y nos dan noticia tambien de cosas en la historia que no se pueden saber sino por solas ellas'; Morales, Las antigüedades de las ciudades, vol. 1, pp. 80-82.-

53 Morales, Las antigüedades de las ciudades, vol. 2, p. 8.

54 'Tambien está en estas laderas el religiosísimo Monasterio de los descalzos de San Francisco con nombre del Arrizafa, que en Arábigo quiere decir huerto real ... le compete bien su nombre'; Morales, Las antigüedades de las ciudades, vol. 2, p. 15.

55 Morales, Las antigüedades de las ciudades, vol. 2, p. 27

56 'Tuvo tambien Córdoba en aquellos tiempos de los Moros insignes hombres en ingenio y letras, el famoso Averroys, y con él Abezoar, Rasis, Abenragel, y otros muchos ... Tuvo 
Mercedes García-Arenal and Fernando Rodríguez Mediano have argued, the Expulsion of the Moriscos allowed for a less problematic use of Arabic in Spanish historical writings, Morales framed his discussion of Cordoba's Islamic legacy and the region's Arabic toponyms with praises to the city's fertility and propitious climate. ${ }^{57}$ By relying on the tradition of the laudes Hispaniae Morales highlighted the powerful effect that Spain's naturally good landscape had even on infidels and their language, thus tempering possible objections over his attempts to incorporate Arabic toponyms in his reconstruction of Spain's history. ${ }^{58}$

While Morales understood the presence of Arabic names scattered throughout Spain as one of the lingering consequences of a political rupture centered squarely in the Middle Ages, Diego de Guadix conceived of these words as vestiges of a much more ancient history. For Guadix, Arabic exceeded in antiquity any other language in the world because it is the Hebrew language, though corrupted, and the Hebrew language was the one spoken by Adam, Noah, and Abraham'. More than a thousand years before the birth of Muhammad, the world was already replete with Arabic verbs and nouns. The threats assailing Arabic in the sixteenth century compelled Guadix to finally clarify this tongue's genealogy and prove its nobility, since it could claim to be the most immediate ancestor of the sacred tongue.

Increasing tensions over the sincerity of the Moriscos' Catholicism, coupled with anxieties over these communities' integration into Spanish society, prompted the appearance of forgeries like the well-studied Lead Books of Sacromonte. The Lead Books were a set of plaques with Latin and Arabic inscriptions found on the outskirts of Granada between 1595 and 1599. These artifacts allegedly contained writings of first-century Christians who spoke Arabic and had suffered martyrdom under the Roman Empire. The Lead Books and other falsifications attempted to provide evidence for alternative histories that set the arrival of Arabic in Spain centuries before the birth of Muhammad,

Reyes y Capitanes valerosos en la Guerra, y de tan grandes hazañas en ella, que nunca nuestras historias acaban de lamentar los daños que nos hiciéron. Y aunque estos eran Moros, nacian en Córdoba, y el ser infieles no les quita su grandeza y alto ser en el bien natural'; Morales, Las antigüedades de las ciudades, vol. 2, p. 28.

57 Mercedes García-Arenal and Fernando Rodríguez Mediano, The Orient in Spain: Converted Muslims, the Forged Lead Books of Granada and the Rise of Orientalism, (trans.) Consuelo López-Morillas (Leiden: Brill, 2013), pp. 351-69.

$5^{8}$ Victoriano Roncero, 'Las 'Laudes Hispaniae' de San Isidoro a Quevedo', Analecta malacitana, 16 (1993): pp. 81-92. Garibay employs a similar strategy. See: Garibay, 'De las alabanças y loores de España', in Los XL libros del compendio historial de las chronicas y universal historia de toda España (Antwerp: Christophe Plantin, 1571), book III, pp. 6o-81, 78. 
the rise of Islam, or the arrival of Muslim conquerors from Northern Africa. These ancient Arabs were Christians and travelled in the company of exalted figures including the apostle St James and the martyr-saints Cecilius, Thesifon, and Hiscio. ${ }^{59}$ The ultimate goal of these numerous falsifications, as GarcíaArenal and Rodríguez Mediano have shown, was to 'establish the legitimacy of the Moriscos and Conversos by tracing the presence of such converts to Spanish antiquity and dissociating their cultural characteristics from their religious ones'.60

Rather than focus, like the forgers, on the putatively ancient arrival of distinguished Hebrew and Arabic speaking Christians in Spain, Guadix pointed to the similarities between Hebrew and Arabic, adumbrating a theory of linguistic corruption which posited a greater proximity between the two languages than the later emergence of Greek and Latin. This strategy had already been applied by an anonymous grammar published in the city of Louvain in 1559 .

This Gramática de la lengua vulgar de España sought to explain the particularities of the Castilian language to French students. ${ }^{61}$ The author of the Gramática challenged the use of the adjective Castilian to describe the vernacular spoken in much of the Iberian Peninsula. In his hierarchization of languages of Spain he employed two criteria. The first was a particular language's proximity to Hebrew, and the second was the availability of works in that tongue. After Basque, the author contended, the second language of Spain was Arabic, 'which is truly Hebrew'. This language possessed this secondary place 'not only because of its ancient and noble descent, but because many Spaniards had composed in it 'many useful books in all the liberal arts'. Arabic was spoken in the kingdom of Granada and in parts of the kingdoms of Andalusia, Valencia and Aragon. ${ }^{62}$ Castilian, by contrast, came fourth, after

59 García-Arenal and Rodríguez Mediano, Un Oriente español; García-Arenal, 'The Religious Identity of the Arabic Language and the Affair of the Lead Books of Sacromonte of Granada', Arábica, 56 (2009): pp. 495-528; Rodríguez Mediano, 'Fragmentos de orientalismo español del s. XVII', Hispania. Revista española de historia, 66 (2006): pp. 243-76; and Katie A. Harris, 'Forging History. The Plomos of Granada in Francisco Bermúdez de Pedraza's Historia eclesiástica', Sixteenth-Century Journal, 30 (1999): pp. 945-66.

6o García-Arenal and Rodríguez Mediano, 'Jerónimo Román de la Higuera and the Lead Books of Sacromonte', in The Conversos and Moriscos in Late Medieval Spain and beyond (Leiden: Brill, 2009), pp. 243-68; Also see: Katrina B. Olds, Forging the Past: Invented Histories in Counter-Reformation Spain (New Haven: Yale University Press, 2015).

$61 \quad$ Gramática de la lengua vulgar de España, impresa en Lovaina por Bartolomé Gravio en 1559 (Zaragoza: La Derecha, 1892).

62 'por esta solo, que, despues de los Araves, no se han escrito en toda España tantos, tan buenos, i tan fotiles libros en prosa yi metro, como en esta lengua Catalana'; Gramática de la lengua vulgar, p. 18. 
Basque, Arabic, and Catalán. ${ }^{63}$ Regardless of his views concerning the naming of Castilian, the author, like Guadix, on the basis of Arabic's proximity to Hebrew, assigned this language more prestige than the vulgar language that derived from Latin.

While the long controversies over the Lead Books of Sacromonte raged throughout the most important scholarly circles in Spain, Guadix was appointed as interpreter of the Arabic language of the Inquisition tribunal in the city of Granada and its kingdom in 1582. In the 1590s, singled out for his alleged linguistic expertise, he travelled to Rome to serve also as an interpreter and translator of texts for the papacy. ${ }^{64}$ Around this time Guadix composed his Recopilación de algunos nombres arábigos (Compilation of Some Arabic Names that the Arabs Gave to Some Cities and Many Other Things, 1593). In the work's inaugural pages Guadix presented a number of forewarnings in anticipation of criticisms over his etymological artistry. According to Guadix, since Arabic resembled Hebrew, the first language of mankind, more closely than Greek, Latin or Basque this meant that it must predate them. Consequently, Arabic must have been spoken in Spain, Italy, France, and the rest of Europe prior to the birth of Muhammad, the emergence of Islam, and the Islamic conquest of Visigothic Hispania in the eighth century. If a word appeared common to Arabs, Spaniards, Italians, or any other people, it was incorrect, given Arabic's ancient age, to claim that Arabic borrowed it from any of these derivative languages. Even though their primary identity might be difficult to detect 'because their letters, syllables and accents are so altered and moved', these were in fact Arabic dictions.

Guadix applied his linguistic chronology to reject the Greek and Basque etymologies of the name of Spain. He argued that scholars like Morales and Poza should have known that Arabic was, in fact, the most primitive tongue spoken in ancient Iberia, and thus the source of this central name. Hispania, in light of its Arabic origin, was a composite word made up of $e x$ or thing and bania or building, together signifying 'thing that has been built'. Ex-bania, with the passing of time, became the corrupted word known to all as España. ${ }^{65}$ As this

63 'Por las quales causas, i otras q adrede callo, me parescio nombrarla no Española, ni Castellana, sino Vulgar, como siempre la llamaré en toda esta obra'; Gramática de la lengua vulgar, pp. 19-21.

64 On the life of Diego de Guadix, see E. Bajo Pérez and F. Maíllo Salgado, 'Estudio Introductorio', in Guadix, Recopilación de algunos nombres arábigos, pp. 115-31; Darío Cabanelas, 'Tres arabistas franciscanos de los siglos XVII y XVIII', in Homenaje a la profesora Elena Pezzi (Granada: Universidad de Granada, 1992), pp. 21-36.

65 'Todos no han herido en la vena, por no saber que este es nombre arábigo, y por no ser hombres arábigos para saberlo interpretar. Consta pues de ex, i., aliquid, y de bania, que 
example showed, time brought about the decomposition and corruption of words. This process of linguistic deterioration was aggravated by the fact that men who did not know the words' true meanings (or even how to properly articulate Arabic's sounds) progressively transformed them. Arriving at the original uncorrupted form of the diction required the etymologist to give them 'a thousand turns ... or to guess, in order to divine their meaning[s] and integrity in Arabic'. Even though the process might seem arbitrary at times, it was nonetheless supported by the genetic relationship that existed between Arabic, Hebrew and their descendant languages. The verb abrigar, for instance, which Poza had believed to be a Basque suffix of Spain's most ancient language, was clearly a composite of two Arabic units, berr and gar. In Arabic berr meant field or desert and gar meant cave or lair. All together the word berrgar signified 'field cave', and 'to this algarabía', Castilian speakers put an (a) in front and in their fashion they corrupted the word to abrigar. ${ }^{66}$

Another important set of proofs that demonstrated the antiquity of Arabic, and its independence from Islam, was the fact that toponyms of this language persisted in places where Iberia's post-711 Muslim inhabitants had never set foot. When the Spanish conquerors arrived in the West Indies they found many words that, as Guadix could easily show, possessed Arabic ancestry. The plant caçabi, for instance, which the natives of those lands ate, originated in the Arabic caçab, which signified 'reed'. ${ }^{67}$ Likewise on the basis of phonetic similarity, Guadix contended that the word cacique, 'lord of the town', emanated from the Arabic caciq, which meant 'religious [man]'. The name was appropriate since he learned from reading the chronicles of those lands that the principal lord of the town, while ruling over the republic, also had to teach religion and good customs.' 68

significa albañiría o cosa de fábrica o edificio'; Diego de Guadix, Recopilación de algunos nombres arábigos que los árabes pusieron a algunas ciudades y a otras muchas cosas [1593], (ed.) E. Bajo Pérez and F. Maíllo Salgado (Gijón: Trea, 2005), p. 6o1; On Guadix and his context see García-Arenal and Rodríguez Mediano, The Orient in Spain, pp. 36773 .

66 'darles mill bueltas o, si se puede dezir, adiuinar, para llegarlos a su razón y integridad arábiga'... 'Dizen en España para significar dar calor o guarecer de la inclemencia, Viene d'esta palabra, berr, que en arábigo significa campo o desierto, y de gar, que significa cueva o guarida; asi que todo junto, sera berrgar, que significará cueva de campo o guarida de campo'; Guadix, Recopilación, p. 174.

67 Guadix, Recopilación, pp. 456-57.

68 Guadix, Recopilación, p. 461. 
Even the names of regions had Arabic origins. The territories that comprised the wealthy viceroyalty of Peru were named in this way due to the landscape's physical attributes. Peru, like abrigar, also came from the Arabic berr. In this case, however, the word had been transformed differently, the $(u)$ in the end corresponded to the 'the third person affix', so together the word signified 'his field or desert'.69 Guatemala and Mexico could also be similarly etymologized in Arabic proving incontrovertibly that in these distant lands where no Muslims had ever been, and Christians had only recently reached, Arabic had once been spoken as the most primitive language of its inhabitants.

\section{Challenges to the Etymological Method}

Linguistic change, Aldrete believed, was relentless and often unpredictable. In Del origen y principio de la lengua castellana (1606), Aldrete criticized scholars, like Poza or Arias Montano, who relied exclusively on etymological derivations to prove either the primitiveness of the Basque language or the identification of certain geographical spaces in Spain and in the New World with Biblical toponyms. The appellative Peru, which had sparked the Arabic imagination of Guadix, for instance, not only did not come from Arabic, but had also been misinterpreted by those who traced it back to Hebrew. Peru, according to Aldrete, was not a corrupted form of the word Parvaim, and there was no evidence to show that the 'Gold of Ophir was brought to King Solomon from Pirú'. José de Acosta (1539-1600) and Garcilaso de la Vega (1539-1616), two authorities on the languages and histories of the peoples of the New World, also denied the etymology. ${ }^{70}$ Rather, they asserted that when Spaniards reached those parts they asked an Indian what land they were in and 'without

69 Guadix, Recopilación, p. 883.

70 'Mas la etimología del nombre Ophir, y reduccón al nombre de Pirú, téngolo por negocio de poca sustancia, siendo - como es cierto - que ni el nombre del Pirú es tan antiguo ni tan general a toda esta tierra. Ha sido costumbre muy ordinaria en estos descubrimientos del Nuevo Mundo poner nombres a las tierras y los puertos de la ocasión que se les ofrecía; y así se entiende haber pasado en nombrar a este reino Pirú. Acá es opinión que de un río en que a los principios dieron los españoles, llamado por los naturales Pirú, intitularon toda esta tierra Pirú. Y es argumento de esto que los indios naturales del Pirú ni usan ni saben tal nombre de su tierra. Al mismo tono parece afirmar que Sefer en la Escritura son estos Andes, que son unas sierras altísimas del Pirú. Ni basta haber alguna afinidad o semejanza de vocablos, pues de esa suerte también diríamos que Yucatán es Yectán, a quien nombra la Escritura; ni los nombres de Tito y de Paulo que usaron los reyes ingas deste Pirú se debe pensar que vinieron de romanos o de cristianos, pues es muy ligero 
understanding, he answered Beru, Pelu. ${ }^{\text {'1 }}$ The natives of those territories referred to their kingdom as the Tuantinsúiu, which signified the four parts of their reign, and had never used the word Peru to describe their domains. Phonetic similarities were insufficient to establish historical concordance. Francisco Cervantes de Salazar (1514?-75), the first official chronicler of Mexico City, made a similar claim about the toponym Yoqtan. When the Spanish first reached the coast of Mesoamerica and the Yucatan Peninsula they met 'certain men who, when asked the name of the large town nearby, responded by saying 'Tectetlan' which means 'I do not understand you'. The Spanish, thinking that the town was called this way, corrupted the word and have referred to the region as Yucatán down to the present. ${ }^{72}$

In addition to this confusion, languages borrowed words unscrupulously. The dense etymological histories of the previous decades had made clear that Castilian itself contained lexical units from Gothic, Arabic, Greek and the languages of the New World. Toponyms, then, might not necessarily represent a direct path towards origins, since a locale could be named with borrowed or translated words, presenting numerous and unpredictable intermediary factors that muddled the relationship between the intention of the name-makers and the most ancient or original meaning of the word. Etymological arguments, for Aldrete, were consequently a dangerous topic to deal with 'because [one] walked only on ... uncertain proofs, depending on words so inclined to changing. ${ }^{73}$

Aldrete was immersed in a discussion over the origins of the Castilian language. He had to suffer the consequences of his defense of the theory that Castilian was corrupted Latin and not a primordial language in itself. In writing against the theory of Gregorio López Madera (1562-1649), Aldrete

indicio para afirmar cosas tan grandes'; José de Acosta, Historia natural y moral de las Indias, (ed.) Fermín del Pino-Díaz (Madrid: csic, 2008), book I, ch. XIII, pp. 26 -27.

$71 \quad$ Bernardo de Aldrete, Del origen, pp. 356-57.

72 'Poco más adelante, hallaron ciertos hombres que, preguntados cómo se llamaba un gran pueblo que estaba allí cerca, dixeron Tectetlan que quiere decir 'no te entiendo'; pensando los españoles llamarse así, y corrompiendo el vocablo, le llamaron Yucatán hasta hoy; Francisco Cervantes de Salazar, Crónica de la Nueva España, que escribió el dr. D. Francisco Cervantes de Salazar, cronista de la imperial ciudad de México (Madrid: The Hispanic Society of America, 1914), book II, ch. I, p. 61.

73 'es negocio lleno de riezgo, i peligro tratar desto porque se camina con solo indicios, i pruevas inciertas, dependientes de palabras tan ligeras de mudarse'; Aldrete, Del Origen, p. 284 . 
concluded that the reasons that compel people to name certain places are diverse and that words change in response to a multiplicity of factors, which are often unaccountable or unpredictable. Furthermore, as Kathryn Woolard has argued, Aldrete's investigations of the causes of linguistic change and their correlation with political, climactic, and social conditions led him to a drastic conclusion on the immutability of origins. Under the proper circumstances, Woolard claimed, Aldrete found that 'communities give up their deeply held languages and customs, acquire new ones, and form new social bonds, and loyalties, to the point of becoming indistinguishable from former enemies. ${ }^{74}$ Ancient Iberians adopted Latin, in the same way that the inhabitants of the New World were abandoning their tongues in favor of Castilian.

While Aldrete sought to understand the specific principles that governed linguistic change, he challenged the idea that linguistic remains could provide a reliable trail to origins, for 'words alone are bound to be forever, being the lightest of things, lighter than the wind, the most subject to change.' The study of ancient names and their meanings could not serve as proof of origins unless their presence and usage was attested in multiple 'truthful histories', and even then they were to be approached with much caution..$^{75} \mathrm{He}$ who takes names as the sole proof of origins, Aldrete concluded, 'fools himself truly, to seek in the most unstable and meager thing, perpetuity and firmness. ${ }^{76}$

\section{Conclusions}

In the sixteenth century etymological histories multiplied in response to the religious and social controversies inherent in the integration of Jewish and Muslim converts - and their languages - into a general history of the Iberian

74 Kathryn A. Woolard, 'Is the Past a Foreign Country?: Time, Language Origins and the Nation in Early Modern Spain',Journal of Linguistic Anthropology, 14 (2004): pp. 57-80, 66. Also, Woolard, 'Bernardo de Aldrete, Humanist and Laminario', Al-Qanțara, 24 (2003): pp. 449-76; and 'Bernardo de Aldrete and the Morisco Problem: A Study in Early Modern Spanish Language Ideology', Comparative Study of Society and History, 44 (2002): pp. 44680 .

'por historias ciertas'; Aldrete, Del Origen, p. 284. Also see: Lucia Binotti, La teoría del 'castellano primitivo.' Nacionalismo y reflexión lingüística en el Renacimiento español (Münster: Nodus Publikationen, 1995).

'Dize por cierto mui bien, muerense los hombres, acabense sus Reinos, i possessiones todo se muda con el tiempo, i las palabras solas an de ser para siempre, siendo las mas ligeras que el viento, i mas sujetas a mudanças. Mucho se engaña, por cierto, quien en la cosa mas inestable, i flaca, busca perpetuidad, i firmeza'; Aldrete, Del origen, p. 177. 
Peninsula. In tandem with this, scholars felt compelled to interpret the significance of the many centuries of Islamic rule. The importance of the etymological method for arguing a particular theory of origins, though seemingly absurd to a contemporary reader, is evident. Despite the fact that the writers who sought to harness the mnemonic and historical powers of the etymology often defended irreconcilable perspectives, they collectively tested innovative methods and models of understanding and theorizing linguistic change to approach a common and urgent topic. As their histories accumulated into an interrelated and polemical body of knowledge, it became clear that in many ways the etymology had reached its explanatory limits. ${ }^{77}$

A single word, such as Hispania, Peru, or briga possessed multiple and equally plausible trajectories. The sheer mass of new information, the perspective offered by the mutating linguistic landscape of the New World, and the many contradictory accounts that linked a word to particular histories, destabilized the idea that linguistic vestiges were capable of transmitting the original qualities of their most remote speakers. Challenges to the etymological method and its probatory value would force Spanish humanists of subsequent generations to seek out alternative strategies of contending with Spain's linguistic diversity and of explaining the legacy of its Oriental traditions. ${ }^{78}$

Notwithstanding its detractors, the discipline resurfaced multiple times in the following centuries. The Valencian savant Gregorio Mayáns y Siscar (16991781 ), for instance, sought to reinvigorate the study of etymologies in the middle of the eighteenth century by establishing a method with a canon of specific rules and principles that would allow the etymologist to correctly find the origin of a word..$^{79}$ Mayáns believed that the knowledge of a word's true beginning was essential because primitive names had corresponded to the objects that they signified. This was especially true about Hebrew, the first language of mankind, and the other Oriental languages that were closely related to it. Yet, for all of Mayáns' faith in etymology, he still asserted that it was a separate endeavor from the search for historical truths. Mayáns declared that the 'etymological art is not part of history'. In so doing, he refuted the idea that to search for the origins of a language was the most worthy enterprise that could be performed in the theater of history. No longer could the etymology

77 See Don Cameron Allen, The Legend of Noah: Renaissance Rationalism in Art, Science and Letters (Urbana: University of Illinois Press, 1949).

78 García-Arenal and Rodríguez Mediano, The Orient in Spain, ch. 17.

79 See: María José Martínez Alcalde, Las ideas lingüisticas de Gregorio Mayáns (Valencia: Artes Gráficas Soler, 1992), pp. 145-209; Enrique Jiménez Ríos, 'El cultivo de la etimología en España durante el siglo XVIII', Moenia, 9 (2003): pp. 253-74. 
unveil, as it had done in the centuries before, incontrovertible proofs about the origin of a nation. ${ }^{80}$

80 Gregorio Mayáns y Siscar, Conversación sobre el Diario de los Literatos en España (1737), in Obras Completas, (ed.) Antonio Mestre Sanchis (Valencia: Ayuntamiento de Oliva, 1984), vol. III, p. 427. 